\title{
Allozyme variation in natural and cultured populations in two tilapia species: Oreochromis niloticus and Tilapia zillii
}

\author{
XAVIER ROGNON*, MARTINE ANDRIAMANGA, BRENDAN MCANDREW $†$ \& RENÉ \\ GUYOMARD \\ Laboratoire de Génétique des Poissons, INRA, 78352 Jouy en Josas Cedex, France and †Institute of Aquaculture, \\ University of Stirling, Stirling, FK9 4LA, U.K.
}

\begin{abstract}
We investigated the electrophoretic polymorphism at 30 protein loci in 27 wild and cultured populations of two tilapia species, Tilapia zillii and Oreochromis niloticus. Single and joint segregations were analysed at 12 polymorphic loci in full-sib families. All the loci showed single segregation in agreement with the Mendelian expectations, and two nonrandom joint segregations were found. In total, 26 loci were polymorphic and 12 were diagnostic between the two species. A pronounced differentiation was observed between the Ivory Coast and Nilo-Sudanian T. zillii populations (average Nei's standard genetic distance $=0.13$ ). Within the Nilo-Sudanian region, the level of variation observed in $O$. niloticus and $T$. zillii was rather low when compared with other freshwater species analysed at similar macrogeographical scales. The same pattern of geographical differentiation was found between the west and east African populations in both species suggesting that this structuring mainly reflected the same palaeogeographical events. Most of the geographical variation observed in the Nile tilapia populations analysed here was present in the cultured stocks. In contrast to fish-farmed stocks analysed in other countries, those from the Ivory Coast and Niger displayed neither evidence of loss of genetic diversity nor any trace of introgression with other cultured tilapia species, indicating that these stocks have been properly managed.
\end{abstract}

Keywords: allozyme variation, cultured stocks, Oreochromis niloticus, phylogeography, Tilapia zillii, wild populations.

\section{Introduction}

Among the tilapias, Oreochromis niloticus, the Nile tilapia, is the main species used in aquaculture. Its original range includes the Senegal, Gambia, Niger, Volta, Lake Chad and the Nile river basins as well as several lakes in east Africa (Trewavas, 1983; Fig. 1), but today cultured stocks have been propagated around the world. Most of these stocks originated from the same sampling areas in the Nile and Volta rivers and were founded with a limited number of individuals (Pullin \& Capili, 1988; Welcomme, 1988; Lazard, 1990), regardless of the extant genetic variation within and between natural populations. Furthermore, the propagation of $O$.

${ }^{*}$ Correspondence: Département des Sciences Animales, Institut National Agronomique Paris-Grignon, 75231 Paris Cedex 05, France. niloticus stocks could have been accompanied by a rapid loss of genetic variation within populations through genetic drift in some cases (Brummett et al., 1988; Pullin \& Capili, 1988). Finally, tilapias generally show a strong propensity to hybridize. Intrageneric hybridization has been reported in the wild when originally allopatric species come into contact after transplantation (Daget \& Moreau, 1981) or has been done intentionally by fish-farmers in order to produce all-male populations (Jalabert et al., 1971). This could have led to uncontrolled cryptic and undesirable introgressions of the cultured stocks by other species, as exemplified by allozyme studies on fish-farm populations (Macaranas et al., 1986).

The rational utilization of the genetic resources and the adequate management of cultured stocks of $O$. niloticus (as well as other tilapia species) require two complementary phases: (1) a description of the genetic variation within and between populations 


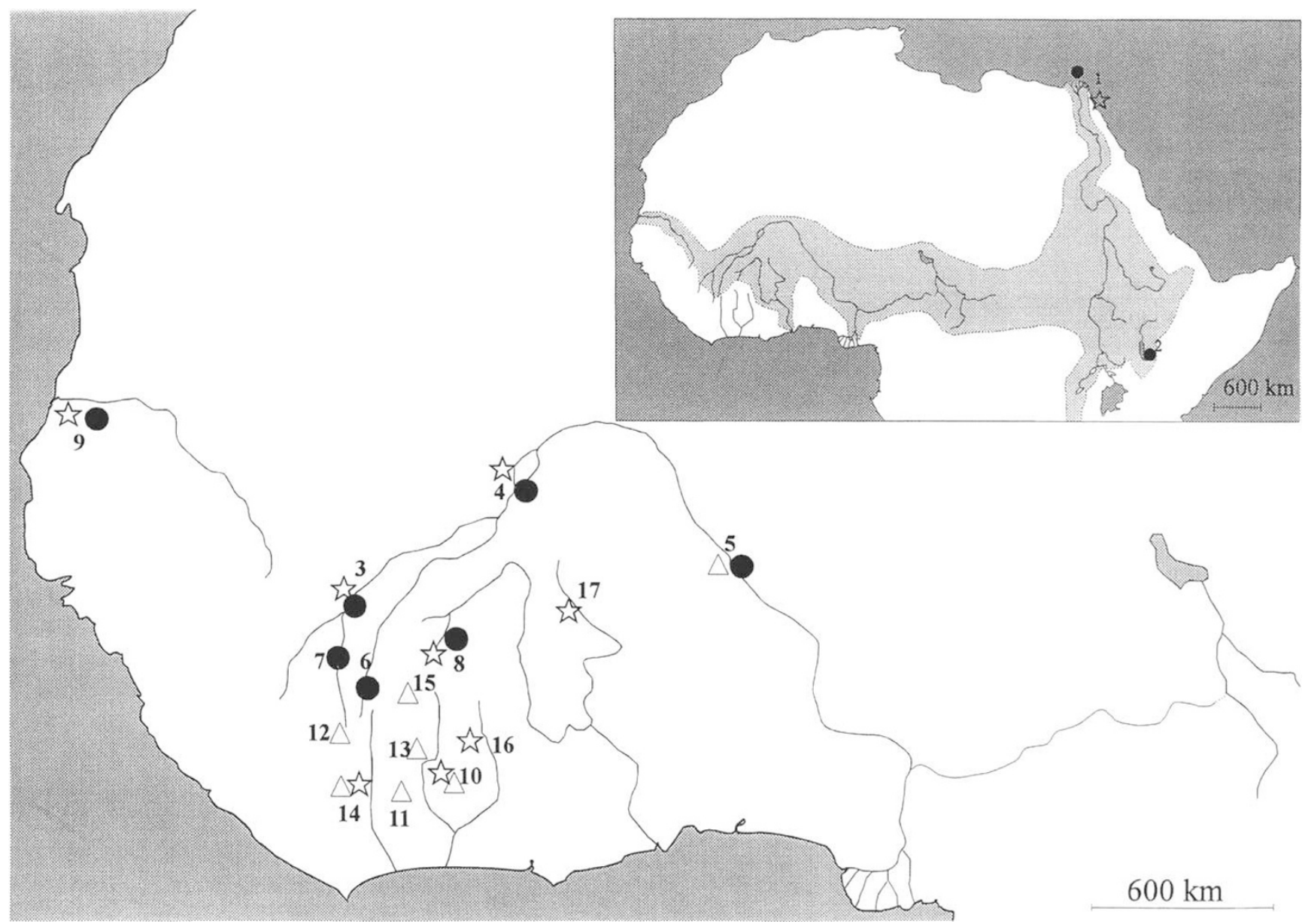

Fig. 1 Geographical locations of Oreochromis niloticus and Tilapia zillii populations sampled: $(\bullet)$ wild and $(\triangle)$ cultured populations of $O$. niloticus and of (ㄱ) T. zillii. Collection sites are numbered as indicated in Table 1 . Shadowed area indicates the natural distribution range of $O$. niloticus.

throughout the complete geographical range of the species and (2) the identification of diagnostic loci which could allow the risks of interspecific introgression with related cultured species to be monitored.

In this paper, we present a first evaluation of allozyme variation in natural populations of $O$. niloticus throughout most of its natural range as well as in cultured stocks used in the Ivory Coast and Niger. We also describe the genetic variation in a related, but not domesticated (at least in west Africa) species, T. zillii, over a similar geographical area for comparison. These results are compared with those already published on tilapia and are discussed in relation to three major questions: (1) how have hydrography, geographical isolation and palaeogeographical events affected the population structure of these species; (2) how have cultured strains changed in comparison to their wild progenitors and (3) what is the level of interspecific gene introgression within these strains?

\section{Materials and methods}

\section{Sampling}

Samples from 15 wild populations of $T$. zillii and $O$. niloticus and nine cultured stocks of $O$. niloticus were collected in west Africa (Fig. 1 and Table 1). Fish were identified by morphological characters as described by Lévêque \& Paugy (1984). The Lake Manzala samples were from the $F_{7}$ generation of experimental stocks maintained at the Institute of Aquaculture (University of Stirling, U.K.). The initial broodstock number was 30 pairs and each generation was obtained by mating a minimum of 50 and 20 pairs for $O$. niloticus and $T$. zillii, respectively. 
Table 1 Origin (river system and location) and size of the 27 samples of tilapia

\begin{tabular}{|c|c|c|c|c|}
\hline Origin & Stock & Abbreviation & $\begin{array}{l}\text { Sample } \\
\text { size }\end{array}$ & $\begin{array}{l}\text { Location } \\
\text { number }\end{array}$ \\
\hline \multicolumn{5}{|l|}{ Oreochromis niloticus } \\
\hline Nile (Lake Manzala - Egypt) & $\mathrm{E}$ & ONnil & 15 & 1 \\
\hline Lake Turkana (El Molo Bay - Kenya) & $\mathrm{E}$ & ONtur & 20 & 2 \\
\hline \multicolumn{5}{|l|}{ Niger } \\
\hline Bamako (Mali) & W & ONnb & 11 & 3 \\
\hline Mopti (Mali) & W & ONnm & 17 & 4 \\
\hline Niamey (Niger) & W & ONnn & 17 & 5 \\
\hline Baoule river (Odiene - Ivory Coast) & W & ONbao & 7 & 6 \\
\hline Sankarani river (Selingue - Mali) & W & ONnsa & 9 & 7 \\
\hline Volta (Kou river at Bama, Burkina Faso) & W & $\mathrm{ONkr}$ & 20 & 8 \\
\hline Senegal (Djoudj) & W & ONsg & 30 & 9 \\
\hline \multicolumn{5}{|l|}{ 'Bouake strain'" } \\
\hline Bouke Station (Ivory Coast) & $\mathrm{C}$ & ONbk & 30 & 10 \\
\hline Daloa 1 (fish farm, Ivory Coast) & $\mathrm{C}$ & ONd1 & 24 & 11 \\
\hline Daloa 2 (fish farm, Ivory Coast) & $\mathrm{C}$ & $\mathrm{ON} d 2$ & 30 & 11 \\
\hline Gbeleban (fish farm, Ivory Coast) & $\mathrm{C}$ & ONgb & 15 & 12 \\
\hline Kossou (manmade lake, Ivory Coast) & $\mathrm{C}$ & ONko & 30 & 13 \\
\hline Buyo (manmade lake, Ivory Coast) & $\mathrm{C}$ & $\mathrm{ON} b u$ & 14 & 14 \\
\hline Kouto (manmade lake, Ivory Coast) & $\mathrm{C}$ & ONkt & 20 & 15 \\
\hline Kou strain (Bouake Station, Ivory Coast) & $\mathrm{C}$ & ONks & 30 & 10 \\
\hline Niger strain (fish farm near Niamey, Niger) & $\mathrm{C}$ & ONni & 27 & 5 \\
\hline \multicolumn{5}{|l|}{ Tilapia zillii } \\
\hline Nile (Lake Manzala, Egypt) & $\mathrm{E}$ & TZnil & 8 & 1 \\
\hline Sassandra (Buyo, Ivory Coast) & W & TZsas & 16 & 14 \\
\hline \multicolumn{5}{|l|}{ Bandama } \\
\hline Kan (Bouake Station, Ivory Coast) & W & TZka & 10 & 10 \\
\hline N’Zi (Brobo, Ivory Coast) & W & $\mathrm{TZnz}$ & 11 & 16 \\
\hline \multicolumn{5}{|l|}{ Niger } \\
\hline Bamako (Mali) & W & $\mathrm{TZn} b$ & 6 & 3 \\
\hline Mopti (Mali) & W & $\mathrm{TZnm}$ & 14 & 4 \\
\hline \multicolumn{5}{|l|}{ Volta } \\
\hline Kou river (Bama, Burkina Faso) & W & $\mathrm{TZ} k r$ & 5 & 8 \\
\hline Red Volta (near Ouagadougou, BF) & W & $\mathrm{TZ} r v$ & 10 & 17 \\
\hline Senegal (Djoudj) & W & TZsg & 4 & 9 \\
\hline
\end{tabular}

$\mathrm{W}=$ wild populations, $\mathrm{C}=$ cultured stock; $\mathrm{E}=$ experimental stocks (see text).

The Lake Turkana sample was provided by the Institut für Tierzucht und Haustiergenetik (University of Göttingen, Germany). This stock was propagated over generations by mating 35 parent pairs since its foundation with individuals collected from the lake. The individuals analysed here belong to the $\mathrm{F}_{3}$ generation and were descended from $10 \quad \mathrm{~F}_{2}$ pairs. This kind of propagation should have prevented significant loss of genetic diversity through genetic drift and these samples should be genetically close to the wild populations from which they originated.

\section{Enzymatic electrophoresis}

Electrophoresis procedures were described by Rognon \& Guyomard (1995), except that MDH was also screened following Macaranas (1991). Allele discrimination was improved by running 14 per cent starch gels at $6^{\circ} \mathrm{C}$. The following enzyme systems were examined in each population: AAT (EC 2.6.1.1), $\mathrm{ADH}$ (EC 1.1.1.1), AK (EC 2.7.4.3), CK (EC 2.7.3.2), EST (EC 3.1.1.-), FBP (EC 3.1.3.11), FH (EC 4.2.1.2), G3PDH (EC 1.1.1.8), GPI (EC 5.3.1.9), IDDH (EC 1.1.1.14), IDHP (EC 1.1.1.42), LDH (EC 1.1.1.27), MDH (EC 1.1.1.37), MEP (EC 
1.1.1.40), MPI (EC 5.3.1.8), PGDH (EC 1.1.1.44), PGM (EC 5.4.2.2) and SOD (EC 1.15.1.1). Locus and allele nomenclature follow Shaklee et al. (1990). Alleles were designated by their electrophoretic mobility relative to the most frequent allele found in the Bouake Station sample of $O$. niloticus.

\section{Inheritance studies}

Four specific $O$. niloticus families were selected according to parental phenotypes. One back-cross family between $O$. macrochir and $O$. niloticus $[O$. macrochir female $\times(O$. macrochir female $\times O$. niloticus male)] was also analysed. Oreochromis macrochir was chosen because of the high number of diagnostic loci found between this species and $O$. niloticus (Rognon \& Guyomard, 1995). Gene segregation was analysed in 62 (back-cross family) and $70(O$. niloticus families) three-month-old offspring per cross.

\section{Data analysis}

Departures of single and joint segregations from expected Mendelian proportions in full-sib families were checked with $\chi^{2}$-tests (Taggart \& Ferguson, 1984). The sequential Bonferroni technique (Rice, 1989) was applied to the tables of multiple statistical tests to correct for table-wide significance levels. Agreement of the observed genotype frequencies with the Hardy-Weinberg and genotypic linkage equilibrium expectations were checked for each sample with the GENEPOP package (Raymond \& Rousset, 1995). Mean expected heterozygosities and standard genetic distances were estimated following Nei (1987). Phenograms were generated by UPGMA cluster analysis (Sneath \& Sokal, 1973) using the PHYLIP package (Felsenstein, 1993). Bootstrap values were computed over 500 replications.

\section{Results}

\section{Genetic interpretation}

A conservative approach was adopted in the classification of loci and variation which resulted in 30 loci which could be reliably typed in these species. Single and joint segregations could be checked at a total of 12 loci (Table 2). All the single segregations fitted the expected Mendelian proportions. Two nonrandom joint segregations were observed: $A A T-2 * /$ $M D H-3^{*}$ (recombination frequency, $r=0.30$ ) and $M P I^{*} / E S T-2 *(r=0.16)$. Significant linkages involving the same enzyme systems were also found in Xyphophorus spp. for these two pairs (Morizot et al., 1991) and in salmonids for the first one (Taggart \& Ferguson, 1984), but locus homologies between these species have not been established.

\section{Polymorphism and heterozygosity levels}

Allele frequencies at the 25 loci are presented in Table 3. All samples were in agreement with the Hardy-Weinberg expectations and no significant linkage disequilibrium was found. Twenty-five loci were found to be polymorphic and 12 of them were diagnostic of the two species. Eleven loci exhibited variation in $O$. niloticus populations. The largest

Table 2 Single (on the diagonal) and joint (off the diagonal) segregation analysis at 12 loci in specific and back-cross (italicized) families of tilapia. Numbers represent the number of families analysed. Segregation in females is indicated below the diagonal and segregation in males above the diagonal

\begin{tabular}{|c|c|c|c|c|c|c|c|c|c|c|c|c|}
\hline & $A A T-2^{*}$ & $C K-1^{*}$ & EST-2* & $F H^{*}$ & $I D D H^{*}$ & $L D H-2^{*}$ & $M D H-1^{*}$ & $M D H-3^{*}$ & $M E P-1^{*}$ & $M E P-2^{*}$ & $M P I^{*}$ & $S O D^{*}$ \\
\hline$A A T-2^{*}$ & 2 & & & & 1 & & & & 1 & & & \\
\hline$C K-1^{*}$ & & 1 & 1 & & & 1 & 1 & 1 & & & 1 & 1 \\
\hline EST-2* & & & 1 & & & 1 & 1 & 1 & & & $1^{* * *}$ & 1 \\
\hline$F H^{*}$ & & & & 1 & 1 & & & & & & & \\
\hline$I D D H^{*}$ & & & & & 3 & & & & 1 & & & \\
\hline$L D H-2^{*}$ & & & & & & 1 & 1 & 1 & & & 1 & 1 \\
\hline$M D H-1^{*}$ & & & & & & & 1 & 1 & & & 1 & 1 \\
\hline$M D H-3^{*}$ & $1^{* *}$ & & & & & & & $1 / 1$ & & & 1 & 1 \\
\hline$M E P-1^{*}$ & & & & & 1 & & & & 2 & & & \\
\hline$M E P-2 *$ & & & & & 1 & & & & 1 & $3 / 1$ & & \\
\hline$M P I^{*}$ & & & & & & & & & & & 1 & 1 \\
\hline$S O D^{*}$ & & & & & & & & & & & & 1 \\
\hline
\end{tabular}

${ }^{* *} P<0.01,{ }^{* *} P<0.001$ : statistical significance at the $\alpha$ table-wide level (Rice, 1989). 


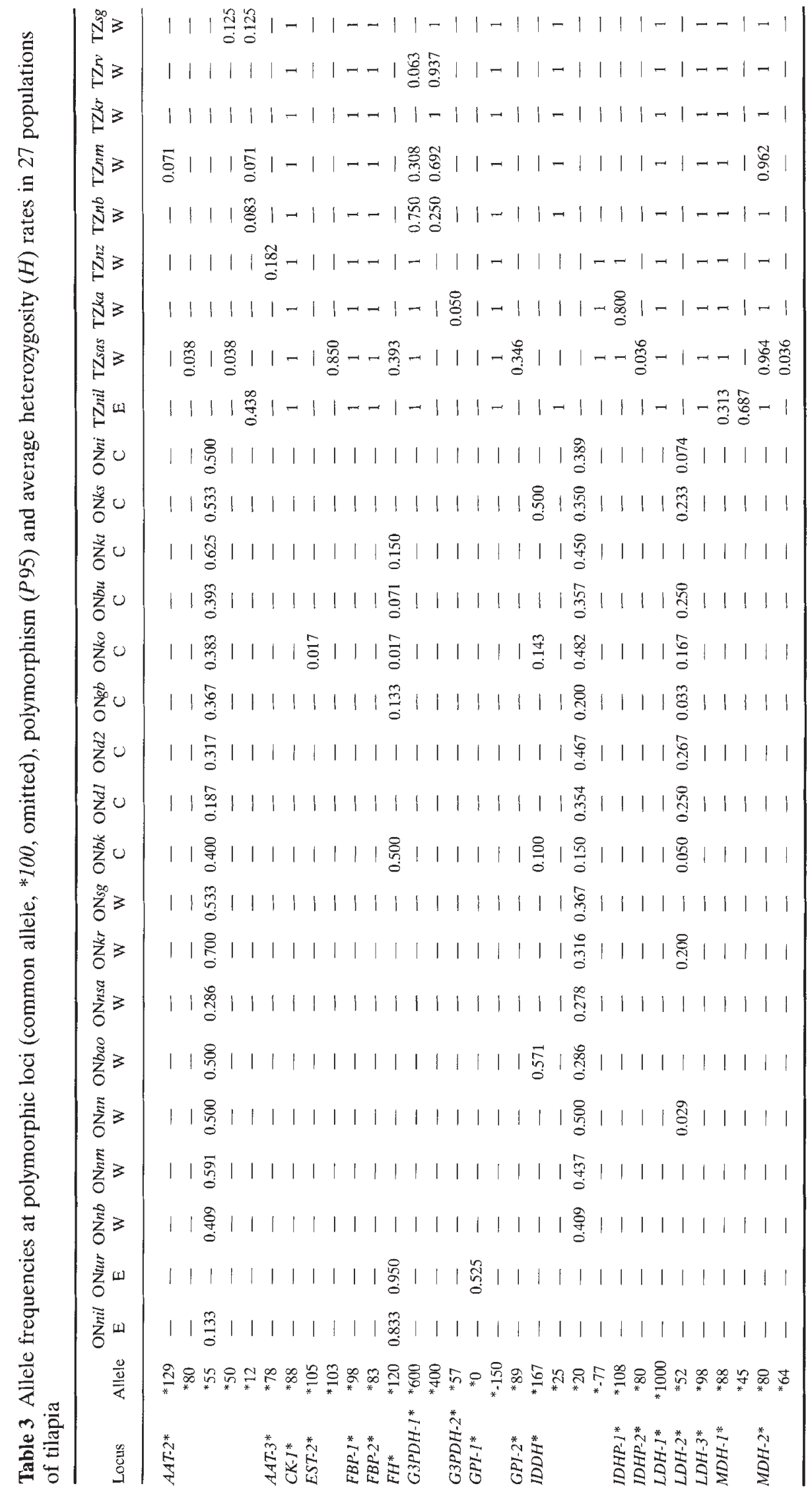




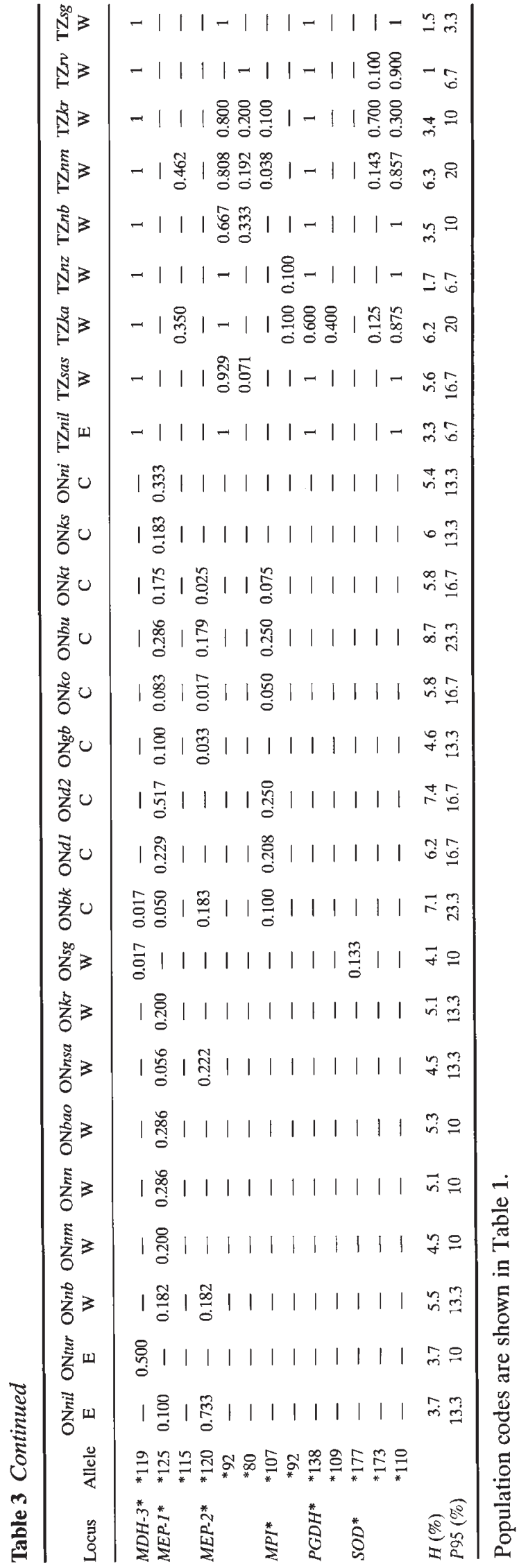

allele frequency differences were found between the eastern and western populations. The cultured stocks derived from the Bouake strain exhibited the largest number of alleles (Mann-Whitney test; $P<0.002)$. $M P I^{*} 107$ was specific to these stocks. Seventeen loci were polymorphic among the $T$. zillii populations. $I D D H^{*}$ was diagnostic of samples from Ivory Coast and the Nilo-Sudanian province and large allele frequency differences were found at $G 3 P D H-1^{*}, I D H P-1^{*}, M E P-2^{*}$ and $S O D^{*}$.

All the populations of both species were polymorphic (Table 3 ). The polymorphism rates (under the 0.95 criterion) ranged from 3.3 to 20 per cent in $T$. zillii, from 6.7 to 13.3 per cent in the wild Nile tilapia populations and from 13.3 to 23.3 per cent in cultured Nile tilapia stocks. The expected average heterozygosity per locus (Table 3 ) ranged from 1 to 6.2 per cent for $T$. zillii, 2-5.5 per cent for wild $O$. niloticus populations and $4.6-8.7$ per cent in cultured $O$. niloticus stocks. They were significantly higher in cultured than in wild populations of $O$. niloticus (Mann-Whitney test, $P<0.002$ ).

\section{Population structure and phenetic relationships}

UPGMA phenograms derived from standard genetic distances (data not shown) for wild populations plus Nile River and Lake Turkana samples, and for all the Nile tilapia populations are given in Fig. 2a and $2 \mathrm{~b}$, respectively. Both species were unequivocally differentiated because the node at each of the species clusters was supported by 100 per cent bootstrap values. Within the two species, the wild populations exhibited a clear geographical clustering pattern (Fig. 2a). In T. zillii, the Ivory Coast populations (TZsas, TZka, TZnz) were clearly distinctive from those of the Nilo-Sudanian region (TZnil, $\mathrm{TZ} n b, \mathrm{TZ} n m, \mathrm{TZkr}, \mathrm{TZ} r v, \mathrm{TZ} g$ ). The mean genetic distance between these two groups was $0.121 \pm 0.029$. A subdivision between eastern and Sudanian populations was found in both $T$. zillii and $O$. niloticus with a similar mean level of differentiation $(0.059 \pm 0.023$ and $0.064 \pm 0.012$, respectively $)$.

In Nile tilapia, the average genetic distance between the Lake Turkana and Lake Manzala populations was quite high when compared to the average genetic distance found within the Sudanian wild populations $(0.041$ vs. $0.006 \pm 0.005)$. Note that the topologies found within species were not supported by high bootstrap values. When we added cultured stocks, the topology remained the same but bootstrap values were lower. In particular, the ONtur and ONnil cluster was supported by a bootstrap value of 36 per cent. The cultured stocks of $O$. 
(a)

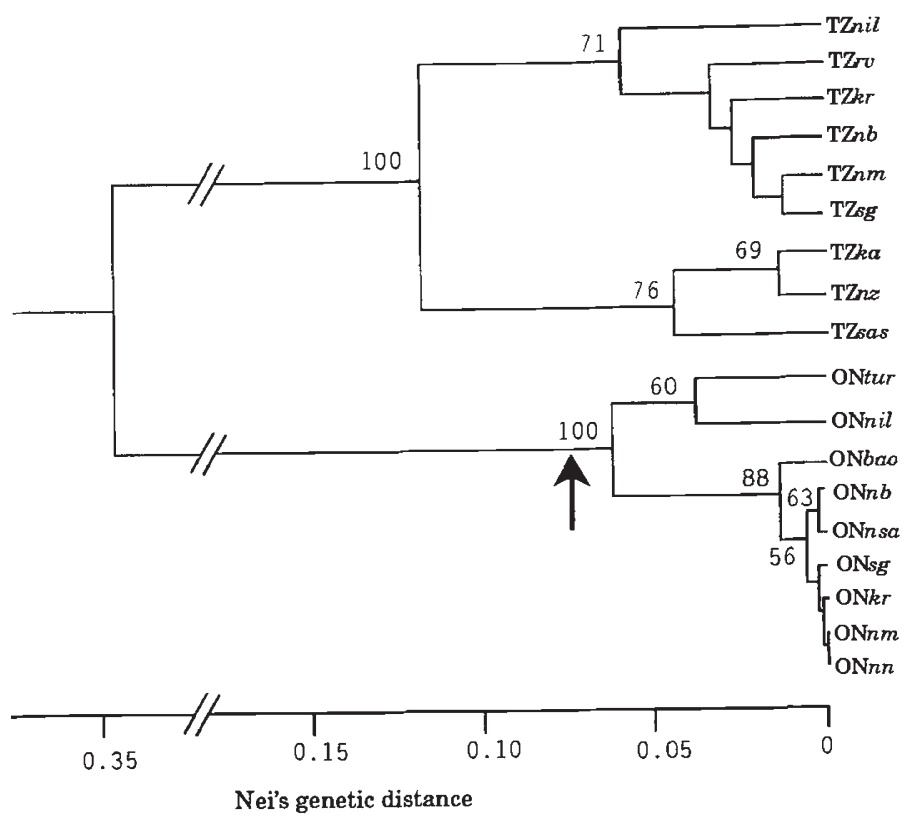

(b)

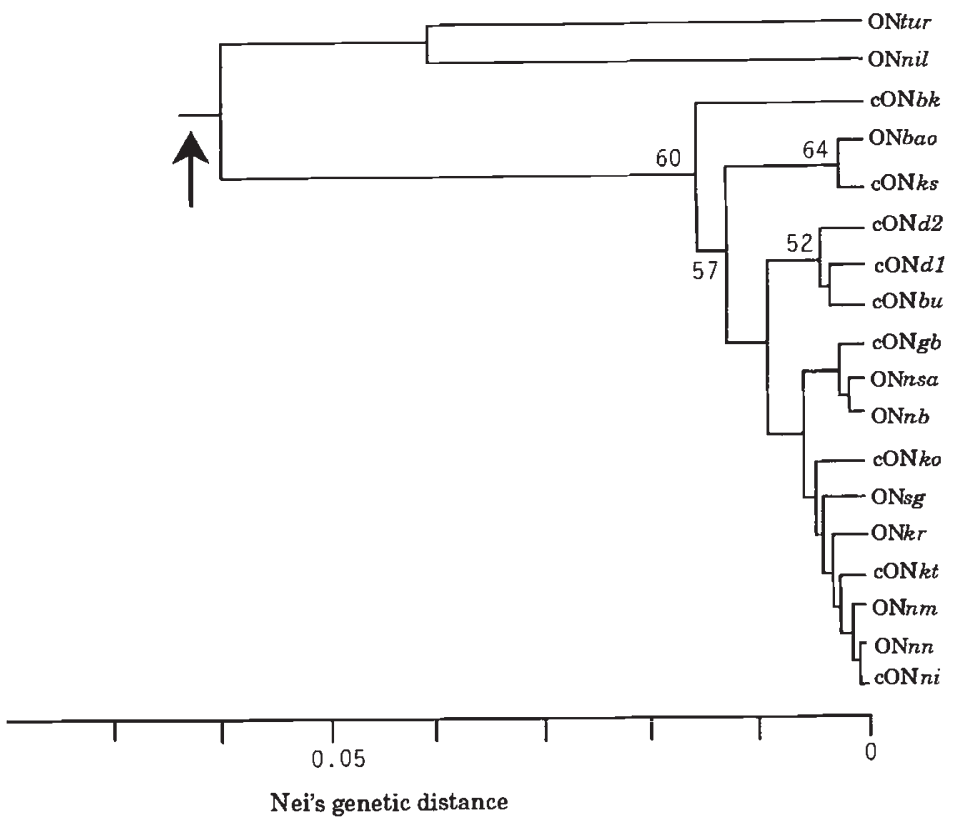

Fig. 2 UPGMA trees derived from standard Nei's genetic distances between wild samples of (a) Tilapia zillii and Oreochromis niloticus or (b) wild and cultured samples of $O$. niloticus. Bootstrap percentage values estimated from 500 replications are reported when higher than 50 per cent. The arrow indicates the position of tree (b) on tree (a). niloticus from the Ivory Coast and Niger clustered to the Sudanian group (Fig. 2b). The Bouake stock was the most divergent population within this group and also the closest one to the Lake Manzala and Turkana samples as a result of its mixed origin. The Niger fish-farm strain (ONni) and the wild population (ONnn) did not differentiate significantly $(P>0.98)$. The wild population from the Kou river $(\mathrm{ON} k r)$ and its cultured derivative stock (ONks) were significantly different $(P<0.001)$. Similar phenograms were obtained using the Fitch \& Margoliash (1967) method and Chord distances
(Cavalli-Sforza \& Edwards, 1967) with slightly lower bootstrap values (results not shown).

The partitioning of the total genetic diversity into between- and within-population components (Table 4) showed that 63.4 per cent of the total genetic diversity $\left(H_{\mathrm{t}}=9.9\right.$ per cent $)$ was the result of between-population differences in $T$. zillii. In $O$. niloticus, 32.8 per cent of the total genetic diversity $\left(H_{\mathrm{t}}=6.9\right.$ per cent) resulted from variation between wild populations, and the gene diversity between cultured stocks accounted for 8.7 per cent of their total gene diversity $\left(H_{\mathrm{t}}=6.9\right.$ per cent $)$. 
Table 4 Gene diversity analysis for Oreochromis niloticus and Tilapia zillii

\begin{tabular}{lcccr}
\hline Species & $\begin{array}{c}\text { No. } \\
\text { populations }\end{array}$ & $H_{\mathrm{t}}(\%)$ & $H_{\mathrm{s}}(\%)$ & $G_{\mathrm{st}}(\%)$ \\
\hline $\begin{array}{l}\text { O. niloticus } \\
\text { West African wild populations plus }\end{array}$ & & & & \\
Nile and Lake Turkana samples & 9 & 6.9 & 4.6 & 32.8 \\
Cultured stocks & 9 & 6.9 & 6.3 & 8.7 \\
All samples & 18 & 7 & 5.5 & 21.4 \\
T. zillii & & & & \\
Ivory Coast & 3 & 6.3 & 4.5 & 28.9 \\
Nilo-Sudanian & 6 & 6 & 3.2 & 47.1 \\
All populations & 9 & 9.9 & 3.6 & 63.4 \\
\hline
\end{tabular}

$H_{\mathrm{t}}$, total gene diversity; $H_{\mathrm{s}}$, average gene diversity within population; $G_{\mathrm{st}}$, relative gene diversity, attributable to the variation between populations.

\section{Discussion}

\section{Genetic variation within and between wild populations}

In most cases, our interpretations of electrophoregrams were consistent with those proposed in previous works (Basiao \& Taniguchi, 1983; McAndrew \& Majumdar, 1983; Seyoum, 1989; Macaranas et al., 1995; Pouyaud \& Agnèse, 1995) and were validated by our inheritance studies for some enzyme systems. The number of loci postulated for AAT, CK, FBP, IDHP and MDH varied between authors, but in all cases, it was possible to establish homology between the loci and the alleles described in the different works. The allele frequencies reported by McAndrew \& Majumdar (1983) on wild $O$. niloticus and $T$. zillii populations from Lake Manzala did not differ from those observed in our samples from the same location. This supports the assumption that the samples analysed here are still representative of original populations of the lake. Differences were found at several loci described by Macaranas et al. (1995) and ourselves for the strains originating from Lake Turkana. As they originated from the same initial sampling of the lake, these differences should result from the subsequent propagation of the strains.

The heterozygosity levels reported here were similar to the values found in other studies on wild O. niloticus populations (McAndrew \& Majumdar, 1983; Seyoum, 1989; Macaranas et al., 1995) or in other tilapia species (McAndrew \& Majumdar, 1983; Seyoum, 1989; Pouyaud, 1994).

The $G_{\text {st }}$ values observed within species in this study are within the range reported for conspecific populations (Gyllensten, 1985). Our study did not include $O$. niloticus populations from the lakes of the Rift Valley, where several morphological subspecies have been recognized (Trewavas, 1983). However, populations from most of these lakes have been analysed by Seyoum (1989) and his results can be compared to ours because his study also included a sample from Lake Turkana. If we assume that the most frequent alleles found in both Lake Turkana samples are the same, the differences between the west and east African lake populations would be mainly the result of variations observed at one locus, out of 25 which were common to the two studies. Accordingly, the $G_{\text {st }}$ value calculated over the entire geographical range of $O$. niloticus should not differ substantially from the value obtained in our study.

According to the morphological classification of Trewavas (1983), the west African and Nile River populations of Nile tilapia belong to the same subspecies, $O$. niloticus niloticus. The pattern of differentiation which emerged from our study is not congruent with this phenotypic classification because the population from the Nile clusters to the Lake Turkana one which was described as a distinct morphological subspecies, O. n. vulcani. Seyoum (1989) also disagreed with the morphological classification as $O$. n. cancellatus did not appear as a monophyletic group in his study. In contrast, Macaranas et al. (1995) observed a dichotomy between $O$. $n$. vulcani and the Nile delta, Volta and Senegal River populations. Examination of additional loci and populations would be necessary to ascertain the phylogenetic relationships between Nile tilapia populations. 


\section{Genetic structure and palaeogeography}

During the last pluvial period, i.e. from 12000 to $7500 \mathrm{BP}$, lakes and rivers expanded dramatically in all the Nilo-Sudanian region and connections were established between the different hydrographic basins investigated in this study (Roberts, 1975; Beadle, 1981; Grove, 1985). It is probable that these recent palaeogeographical events played a role in the genetic structuring of wild populations of Nile tilapia because they allowed gene flow between areas. However, this chronology does not fit with the divergence time which can be estimated from the values of substitution rate usually postulated for proteins under the hypothesis of a molecular clock. McAndrew \& Majumdar (1984) found that the substitution rate used by Gorman et al. (1976) gave estimates of divergence time congruent with those deduced from fossil records in Tilapiines (Roberts, 1975) and seemed to be the most appropriate. When applied to our data, this substitution rate gave a divergence time of $12 \mathrm{Myr}$ since speciation between $O$. niloticus and T. zillii, which is in agreement with McAndrew \& Majumdar (1984), 1.1 Myr between the west and east African $O$. niloticus populations and $0.7 \mathrm{Myr}$ between the Lake Turkana and Nile River populations. The more conservative relationship proposed by Nei (1987) gave coalescence times of $0.3 \mathrm{Myr}$ between west and east African populations and $0.2 \mathrm{Myr}$ between those of Lake Turkana and the Nile River. Despite their inaccuracy, these estimates suggest that the observed genetic distances between the east and west African populations of $O$. niloticus reflect much earlier connections and separations between basins, and differentiation events. It is noteworthy that $T$. zilii and $O$. niloticus show the same level of differentiation between east and west African populations, which suggests that these differentiations reflect the same palaeogeographical events and the same evolution rate in the two species.

In contrast, the three Ivory Coast populations of T. zillii analysed here displayed a large genetic distance from the Nilo-Sudanian ones. The former populations originated from the Baoule $\mathrm{V}$ (Howes \& Teugels, 1989), a region which harbours species from both Nilo-Sudanian and Upper-Guinean provinces. Electrophoretic studies of Nilo-Sudanian species which are found in the Baoule $\mathrm{V}$ were equivocal. Some species, such as Chrysichthys nigrodigitatus (Agnèse, 1989) and T. dageti (Pouyaud, 1994), showed large genetic differentiation between provinces whereas weak genetic differences were found in others such as C. auratus (Agnèse, 1989), Clarias anguillaris (Teugels et al., 1992) or Sarotherodon gali- leus (Rognon, 1993). These different patterns could indicate that there were several colonization events of the Baoule $\mathrm{V}$ by the Nilo-Sudanian ichthyofauna. However, an alternative hypothesis is possible. The rivers of the Baoule $\mathrm{V}$ show a gradation in ichthyofauna. Their lower courses are rain forest habitat with typical Guinean forms, whereas their upper courses are savannah habitat and harbour NiloSudanian forms (Daget \& Iltis, 1965; Lévêque et al., 1983). Thus, the aforementioned differences among species could simply reflect differences in sampling locations.

\section{Genetic comparison between cultured stocks and wild populations}

The cultured Nile tilapia stocks of the Ivory Coast did not exhibit any allele of the other species at diagnostic loci identified in previous analyses of Oreochromis spp. reared in the Ivory Coast (Rognon, 1993; Rognon \& Guyomard, 1995). In contrast, introgression was commonly found in other stocks of Nile tilapia used for aquaculture or stocking (Daget \& Moreau, 1981; Macaranas et al., 1986). In the Ivory Coast, the Bouake Station is the only place where other Oreochromis species are found (Lazard, 1990). However, the O. niloticus stocks present at this station greatly outnumber the other stocks of Oreochromis spp., rendering its contamination by other species improbable. Furthermore, the Ivory Coast- and Niger-farmed stocks always exhibited heterozygosity levels as great as or greater than the natural populations from which they originated, suggesting proper management of these stocks.

Most of the Nile tilapia strains used in aquaculture have not been chosen after an initial evaluation of performances of populations originating from the entire species range. Only recently has the genetic potential of $O$. niloticus been studied in a systematic fashion (Eknath et al., 1993). Our data show that the west African wild populations possess a rather high level of genetic variability. If these wild stocks show satisfactory performances in respect of important economical traits, it could be preferable to use these local strains in fish-farming. This strategy would prevent the importation of a single exotic commercial strain which could have a harmful effect on the genetic diversity of the species.

\section{Acknowledgements}

We would like to thank the Office des Parcs Nationaux du Sénégal, the staff of the ORSTOM Center at Bamako (Mali), G. Horstgen-Schwark (Institut 
für Tierzucht und Haustiergenetik, University of Göttingen, Germany), A. Togueiny (Laboratoire de Physiologie des Poissons, INRA, France), E. Lecoeur (CIRAD-IRCT, Bouake, Ivory Coast) and T. Niaré (Projet Delta Central, Mali) for their co-operation in obtaining samples. We are grateful to G. G. Teugels (Musée Royal de l'Afrique Centrale, Belgium) and J. Maley (ORSTOM, France) for helpful discussions on African ichthyofauna and palaeogeography. This study was supported by grants from the CIRAD-CTFT and CIRAD-EMVT. This work was a part of the Ph.D. thesis of X. R. (supported by a doctoral fellowship from MRT) and was partially carried out at the Institut des Savanes at Bouake (Ivory Coast).

\section{References}

AGNÈse, J. F. 1989. Différentiation Génétique de Plusieurs Espèces de Siluriformes Ouest-Africains Ayant un Intérêt pour la Pêche et l'Aquaculture. Ph.D. thesis, Université des Sciences et Techniques du Languedoc, Montpellier, France.

BASIAO, Z. U. AND TANIGUCHI, N. 1983. An investigation of enzyme and other protein polymorphism in Japanese stocks of the tilapias Oreochromis niloticus and Tilapia zillii. Aquaculture, 38, 335-345.

BEADle, L. G. 1981. The Inland Waters of Tropical Africa. An Introduction to Tropical Limnology, 2nd edn. Langman Inc., New York.

BRUMMETT, R. E., HALSTROM, M. L., DUNHAM, R. A. AND SMITHERMAN, R. O. 1988. Development of biochemical dichotomous keys for identification of American populations of Oreochromis aureus, O. mossambicus, O. niloticus, $O$. urolepis hornorum and Red tilapia. In: Pullin, R. S. V., Bhukasawan, T., Tonguthai, K. and Maclean, J. L. (eds) Second International Symposium on Tilapias in Aquaculture. ICLARM Conference Proceedings, 15, 135-141.

CAVAll1-SFORZA, L. L. AND EDWARDS, A. W. F. 1967. Phylogenetic analysis: models and estimation procedure. Evolution, 21, 550-570.

Daget, J. AND Iltis, A. 1965. Poissons de Côte d'Ivoire (d'eaux douces et saumâtres). Mém. Inst. Fr. Afr. Noire, 74, 1-380.

DAGET, J. AND MOREAU, J. 1981. Hybridation introgressive entre deux espèces de Sarotherodon (Pisces, Cichlidae) dans un lac de Madagascar. Bull. Mus. natl. hist. nat., Sect. A Zool. biol. écol. anim. 2, 689-703.

EKNATH, A. E., TAYAMEN, M. M., PALADA-DE VERA, M. S., DANTING, J. C., REYES, R. A., DIONISIO, E. E. 1993. Genetic improvement of farmed tilapias: the growth performance of eight strains of Oreochromis niloticus tested in different farm environments. Aquaculture, 111, $171-188$.

FELSENSTEIN, J. 1993. PHYLIP (Phylogeny Inference Package), version 3.5c., University of Washington,
Seattle.

FITCH, w. M. AND MARgOliash, E. 1967. Construction of phylogenetic trees. Science, 155, 279-284.

GORMAN, G. C., KIM, Y. J. AND RUBINOFF, R. 1976. Genetic relationships of three species of Bathygobius from the Atlantic and Pacific sides of Panama. Copeia, 2, 361-364.

GROVE, A. T. 1985. The physical evolution of the river basins. In: Grove A. T. (ed) The Niger and its Neighbours. Environmental History and Hydrobiology, Human Use and Health Hazard of the Major West African Rivers, pp. 21-60. A. A. Balkena Publishers, Netherlands.

GYLLENSTEN, U. D. 1985. The genetic structure of fish: differences in the intraspecific distribution of biochemical genetic variation between marine, anadromous and freshwater species. J. Fish Biol., 26, 691-699.

HOWES, G. J. AND TEUGELS, G. G. 1989. New bariliin cyprinid fishes from West Africa, with a consideration of their biogeography. J. Nat. Hist., 23, 873-902.

JALABERT, B., KAMMACHER, P. AND LESSENT, P. 1971. Déterminisme du sexe chez les hybrides entre Tilapia macrochir et Tilapia nilotica. Etude de la sex-ratio dans les recroisements des hybrides de première génération par les espèces parentes. Ann. Biol. Anim. Biochim. Biophys., 11, 155-165.

LAZARD, J. 1990. Transfert de poissons et développement de la production piscicole. Rev. Hydrobiol. Trop., 23, 251-265.

LÉVÊQUe, C. AND PAugy, D. 1984. Guide des Poissons d'Eau Douce de la Zone du Programme de Lutte Contre l'Onchocerchose en Afrique de l'Ouest. Convention ORSTOM-OMS, ORSTOM, Paris.

LÉVÊQUE, C., DEJOUX, C. AND ILTIS, A. 1983. Limnologie du fleuve Bandama, Côte d'Ivoire. Hydrobiologia, 100, 113-141.

MaCARANAS, J. M. 1991. A Practical Laboratory Guide to the Techniques and Methodology of Electrophoresis and its Application to Fisheries Management. Fisheries Technology Manual no. 11. Philippine Council for Aquatic and Marine Research and Development, Les Baños, Laguna, Philippines.

MACARANAS, J. M., TANIGUCHI, N., PANTE, J. R., CAPILI, J. B. AND PULLIN, R. S. V. 1986. Electrophoretic evidence for extensive hybrid gene introgression into commercial Oreochromis niloticus (L.) stocks in the Philippines. Aquacult. Fish. Manag., 17, 249-258.

macaranas, J. M., Agustin, L. Q., ABlan, C. A., PANTE, J. R., EKNATH, A. A. AND PUllin, R. S. V. 1995. Genetic improvement of farmed tilapias: biochemical characterization of strain differences in Nile tilapia. Aquacult. Int., 3, 43-54.

MCANDREW, B. J. AND MAJUMDAR, K. c. 1983. Tilapia stock identification using electrophoretic markers. Aquaculture, 30, 249-261.

MCANDREW, B. J. AND MAJUMDAR, K. C. 1984. Evolutionary relationships within three tilapiine genera (Pisces: Cichlidae). Zool. J. Linn. Soc., 80, 421-435.

MORizOT, D. C., SLAUGENHAUPT, S. A., KALlMAN, K. D. AND Chakravartl, A. 1991. Genetic linkage map of fishes of 
the genus Xiphophorus (Teleostei: Poecilidae). Genetics, 127, 399-410.

NEl, M. 1987. Molecular Evolutionary Genetics, Columbia University Press, New York.

pouyaud, L. 1994. Génétique des Populations de Tilapias d'Intérêt Aquacole en Afrique de l'Ouest. Relations Phylogénétiques et Structurations Populationnelles. Ph.D. Thesis, Université des Sciences et Techniques, Montpellier, France.

POUYAUD, L. AND AGNÈSE, J. F. 1995. Differentiation génétique de plusieurs populations de Sarotherodon melanotheron et Tilapia guineensis de Côte d'Ivoire et du Sénégal. In: Pullin, R. S. V., Lazard, J., Legendre, M., Amon Kothias, J. B. and Pauly, D. (eds), Third International Symposium on Tilapias in Aquaculture. ICLARM Conference Proceedings, $\mathbf{4 1}$ (in press).

PULLIN, R. S. V. AND CAPILI, J. B. 1988. Genetic improvement of tilapias: problems and prospects. In: Pullin, R. S. V., Bhukasawan, T., Tonguthai, K. and Maclean, J. L. (eds) Second International Symposium on Tilapias in Aquaculture. ICLARM Conference Proceedings, 15, 259-266.

RAYMOND, M. AND ROUSSET, F. 1995. GENEPOP (Version 1.2): Population genetics software for exact tests and ecumenicism. J. Hered., 86, 248-249.

RICE, w. R. 1989. Analyzing tables of statistical tests. Evolution, 43, 223-225.

ROBERTS, T. R. 1975. Geographical distribution of African freshwater fishes. Zool. J. Linn. Soc., 57, 249-319.

Rognon, x. 1993. Diversité Génétique et Relations Phylogénétiques chez les Tilapias (Pisces: Cichlidae) - Comparaison des Données du Polymorphisme Enzymatique et
Mitochondrial. Ph.D. Thesis, Université de Paris-Sud, Orsay, France.

ROGNON, x. AND GUYOMARD, R. 1995. Etude de la variation génétique dans les populations domestiques d'Oreochromis sp. In: Pullin, R. S. V., Lazard, J., Legendre, M., Amon Kothias, J. B. and Pauly, D. (eds), Third International Symposium on Tilapias in Aquaculture. ICLARM Conference Proceedings, 41 (in press).

SEYOUM, s. 1989. Stock Identification and the Evolutionary Relationships of the Tilapiine Fishes of the Genera Oreochromis, Sarotherodon and Tilapia (Pisces: Cichlidae) Using Allozyme Analysis and Restriction Endonuclease Analysis of Mitochondrial DNA. Ph.D. Thesis, University of Waterloo, Ontario, Canada.

SHAKLEE, J. B., ALLENDORF, F. W., MORIZOT, D. C. AND WHITT, G. S. 1990. Gene nomenclature for proteincoding loci in fish. Trans. Am. Fish. Soc., 119, 2-15.

SNEATH, P. H. A. AND SOKAL, R. R. 1973. Numerical Taxonomy. W. H. Freeman and Co., San Francisco, CA.

TAGGART, J. B. AND FERGUSON, A. 1984. Allozyme variation in the brown trout (Salmo trutta L.): single locus and joint segregation inheritance studies. Heredity, 53, 339-359.

TEugels, G. G., Guyomard, R. AND LEgendre, M. 1992. Enzymatic variation in African clariid catfishes. J. Fish Biol., 40, 87-96.

Trewavas, E. 1983. Tilapiine Fishes of the Genera Sarotherodon, Oreochromis and Danakilia. British Museum (Natural History), London.

WELCOMME, R. L. 1988. International Introductions of Inland Aquatic Species. FAO Fisheries Technical Paper, 294, 186-211. 